\title{
Atmospheric Effects on the Isotopic Composition of Ozone
}

\author{
Mao-Chang Liang ${ }^{1, * \mathbb{D}}$, Yi-Chun Chen ${ }^{2} \mathbb{D}$, Yi-Qin Gao ${ }^{3}$, Xi Zhang ${ }^{4}$ and Yuk L. Yung ${ }^{5}$ \\ 1 Institute Earth Sciences, Academia Sinica, Taipei 115, Taiwan \\ 2 Research Center for Environmental Changes, Academia Sinica, Taipei 115, Taiwan; \\ yichunchen@gate.sinica.edu.tw \\ 3 College of Chemistry and Molecular Engineering, Peking University, Beijing 100871, China; \\ gaoyq@pku.edu.cn \\ 4 Department of Earth and Planetary Sciences, University of California, Santa Cruz, CA 92697, USA; \\ xiz@ucsc.edu \\ 5 Division of Geological and Planetary Sciences, California Institute of Technology, Pasadena, CA 91125, USA; \\ yly@caltech.edu \\ * Correspondence: mcl@gate.sinica.edu.tw
}

Citation: Liang, M.-C.; Chen, Y.-C.; Gao, Y.-Q.; Zhang, X.; Yung, Y.L. Atmospheric Effects on the Isotopic Composition of Ozone. Atmosphere 2021, 12, 1673. https://doi.org/ $10.3390 /$ atmos 12121673

Academic Editor: Tatiana A. Egorova

Received: 10 November 2021

Accepted: 10 December 2021

Published: 13 December 2021

Publisher's Note: MDPI stays neutral with regard to jurisdictional claims in published maps and institutional affiliations.

Copyright: (c) 2021 by the authors. Licensee MDPI, Basel, Switzerland. This article is an open access article distributed under the terms and conditions of the Creative Commons Attribution (CC BY) license (https:// creativecommons.org/licenses/by/ $4.0 /)$.

\begin{abstract}
The delta values of the isotope composition of atmospheric ozone is $~ 100 \%$ (referenced to atmospheric $\mathrm{O}_{2}$ ). Previous photochemical models, which considered the isotope fractionation processes from both formation and photolysis of ozone, predicted $\delta^{49} \mathrm{O}_{3}$ and $\delta^{50} \mathrm{O}_{3}$ values, in $\delta^{49} \mathrm{O}_{3}$ versus $\delta^{50} \mathrm{O}_{3}$ space, that are $>10 \%$ larger than the measurements. We propose that the difference between the model and observations could be explained either by the temperature variation, Chappuis band photolysis, or a combination of the two and examine them. The isotopic fractionation associated with ozone formation increases with temperature. Our model shows that a hypothetical reduction of $\sim 20 \mathrm{~K}$ in the nominal temperature profile could reproduce the observations. However, this hypothesis is not consistent with temperatures obtained by in situ measurements and NCEP Reanalysis. Photolysis of $\mathrm{O}_{3}$ in the Chappuis band causes $\mathrm{O}_{3}$ to be isotopically depleted, which is supported by laboratory measurements for ${ }^{18} \mathrm{O}^{18} \mathrm{O}^{18} \mathrm{O}$ but not by recent new laboratory data made at several wavelengths for ${ }^{49} \mathrm{O}_{3}$ and ${ }^{50} \mathrm{O}_{3}$. Cloud reflection can significantly enhance the photolysis rate and affect the spectral distribution of photons, which could influence the isotopic composition of ozone. Sensitivity studies that modify the isotopic composition of ozone by the above two mechanisms are presented. We conclude isotopic fractionation occurring in photolysis in the Chappuis band remains the most plausible solution to the model-observation discrepancy. Implications of our results for using the oxygen isotopic signature for constraining atmospheric chemical processes related to ozone, such as $\mathrm{CO}_{2}$, nitrate, and the hydroxyl radical, are discussed.
\end{abstract}

Keywords: ozone; mass-independent effect; Harley and Huggins bands; Chappuis band; photochemistry; pollution chemistry

\section{Introduction}

Atmospheric ozone possesses significant non-mass-dependent isotopic composition [1-12]. This isotopic signature can be transferred to other chemical species such as hydroxyl radical, nitrate, sulfate, carbon dioxide, and nitrous oxide [6,7,13-26], through reactions with ozone or $\mathrm{O}\left({ }^{1} \mathrm{D}\right)$ produced by ozone photolysis in the Hartley and Huggins bands. The resulting non-zero $\Delta^{17} \mathrm{O}\left(=\delta^{17} \mathrm{O}-0.52 \times \delta^{18} \mathrm{O}\right)$ provides useful tracers for constraining biogeochemical cycles involving those chemical compounds. Here, $\delta^{\mathrm{n}} \mathrm{O}$ is defined as

$$
\delta^{\mathrm{n}} \mathrm{O}=\left(\left[{ }^{\mathrm{n}} \mathrm{O}\right] /\left[{ }^{16} \mathrm{O}\right]\right)_{\text {sample }} /\left(\left[{ }^{\mathrm{n}} \mathrm{O}\right] /\left[{ }^{16} \mathrm{O}\right]\right)_{\text {reference }}-1,
$$

where ${ }^{\mathrm{n}} \mathrm{O}={ }^{17} \mathrm{O}$ or ${ }^{18} \mathrm{O}$. The reference used in this paper is atmospheric $\mathrm{O}_{2}$. To use this special isotopic signature for practical applications requires a precise understanding of sources of $\Delta^{17} \mathrm{O}$. Recent models $[5,6]$ that included known isotopic fractionation processes 
can capture the magnitude of the isotopic value of ozone, but the model $\delta$-values were $>10 \%$ higher than the observed. This suggests missing sources or processes that isotopically deplete ozone. In this paper, we reevaluate the known mechanisms (ozone formation and photolysis) and examine the photolysis in the Chappuis band and atmospheric parameters such as temperature, pressure, and clouds that could affect the isotopic composition of ozone.

In this paper, we test four processes in six separate models (Table 1). The Caltech/JPL KINETICS model is used in our study. All models apply the modified zero-point-energy (ZPE) theory $[27,28]$ for the isotopic fractionation in the Hartley and Huggins bands. The four effects considered here include temperature, pressure, photolytic fractionation in the Chappuis band, and cloud scattering. The reference model is one-dimensional (1-D) and considers an altitude-dependent profile of temperature and eddy coefficients, that can best describe globally averaged atmospheric temperature and vertical transport (see [5] and references contained therein for details). The main reason for choosing 1-D, instead of 3-D, is that alteration of ozone normally occurs predominantly in the dayside atmosphere where local photochemical equilibrium is attained. As a result, the fractionation that defines the isotopic composition of atmospheric ozone is affected dominantly by the processes of formation and photolysis, the two main factors explored here. To better compare with the observational data across latitudes in different seasons, we also run 2-D models. The ozone isotope chemistry model is taken from Liang et al. [5], which was built at the low-pressure limit for ozone formation, with modifications (see the following sections).

Table 1. List of processes considered in the photochemical models.

\begin{tabular}{lcccc}
\hline & Temperature & Pressure & Photolysis & Cloud \\
\hline Model A & Nominal & Y & Modified & N \\
Model B & Nominal & N & Modified & N \\
Model C & Nominal & Y & Scaled & N \\
Model D & Reduced & Y & ZPE & N \\
Model E & Nominal & Y & ZPE & N \\
Model F & Nominal & Y & Modified & Y \\
\hline
\end{tabular}

Models A-C and E-F use the nominal temperature profile (see Figure 1 of Liang et al. [5]). Reduction in the temperature profile is applied to Model D. Pressure dependence in fractionating the isotopic composition of ozone during its formation is considered in Models A and C-F; the low-pressure limit is assumed in Model B (same as [5]). Due to insufficient data for the isotopic fractionation caused by the photolysis in the Chappuis band, three different calculations are applied. ZPE theory [29] is assumed in Models D-E, and the rest use a laboratory-based calculation. See later sections for details. To check the validity of the adopted fractionations, we compare the calculated values with recently measured numbers at several wavelengths in the Chappuis band [30-32].

This paper is divided into five parts. The impacts of pressure, temperature, and Chappuis band photolysis on the isotopic composition of $\mathrm{O}_{3}$ are examined in Sections 2-4, respectively. A discussion and conclusions follow in Section 5.

\section{Pressure Dependence}

In previous calculations [5,6], the low-pressure limit (i.e., stratospheric condition) is emphasized. It is known that the isotopic enrichment of ozone decreases with increasing pressure [33], and hence, we expect that taking into account the pressure-dependence of the isotopic fractionation occurred during ozone formation would help reduce the difference between the model and observations at the surface.

The pressure dependence is weak at pressures less than 100 mbar but becomes significant at a higher pressure. For example, $\delta^{50} \mathrm{O}_{3}$ (or enrichment) decreases by $\sim 30 \%$ at pressures from 100 to 1000 mbar [33,34]. We follow Marcus and Gao's model [35-37] for the pressure-dependent calculation of each isotope-variant rate coefficient and parameter- 
ize them following a semi-analytic approach derived by Gao and Marcus [34]; the ozone formation model adopted in this study is the same as that in Liang et al. [5]. (The same approach was also taken previously by Wiegel et al. [23].) We fit the fractionation $\varepsilon$ of each rate coefficient at a given temperature by

$$
\varepsilon=\varepsilon_{0} /\left(1+\mathrm{P} / \mathrm{P}_{1 / 2}\right)
$$

where $\mathrm{P}$ is the atmospheric pressure and $\mathrm{P}_{1 / 2}$ is the pressure at which $\varepsilon$ takes one-half of the value of its low-pressure limit $\varepsilon_{0}$. Both $\mathrm{P}_{1 / 2}$ and $\varepsilon_{0}$ are isotope-variant and temperaturedependent. The latter is presented by Liang et al. [5], and the functional dependence of $\mathrm{P}_{1 / 2}$ is rather complicated; the effective $\mathrm{P} 1 / 2$ of $\delta^{50} \mathrm{O}_{3}\left({ }^{16} \mathrm{O}^{16} \mathrm{O}^{18} \mathrm{O}+{ }^{16} \mathrm{O}^{18} \mathrm{O}^{16} \mathrm{O}\right)$ at $300 \mathrm{~K}$ is 2.6 bar. The resulting pressure dependence from the expression agrees well with the results from experiments [33] and a more sophisticated model [36]. Figure 1 compares the model profile of $\delta^{50} \mathrm{O}_{3}$ for cases with (Model A) and without (Model B) the pressuredependence; the temperature profile is the same as that used previously [5]. The surface temperature is $283.4 \mathrm{~K}$ and the resulting $\delta^{50} \mathrm{O}_{3}$ is $\sim 80 \%$ o for Model $\mathrm{E}$, which is much improved over the previous low-pressure limit model [5]. The new value is consistent with tropospheric measurements at similar temperatures [2,8] but inconsistent with Model A because of considering the photolysis-induced isotope fractionation in the Chappuis band (see Section 4). A likely explanation is that the ozone is largely affected by the Leighton cycle (and $\mathrm{NO}_{x}-\mathrm{CO}-\mathrm{VOC}-\mathrm{O}_{3}$ photochemistry), not the Chapman chemistry for a clean atmosphere we emphasize here. See later sections for further discussion.

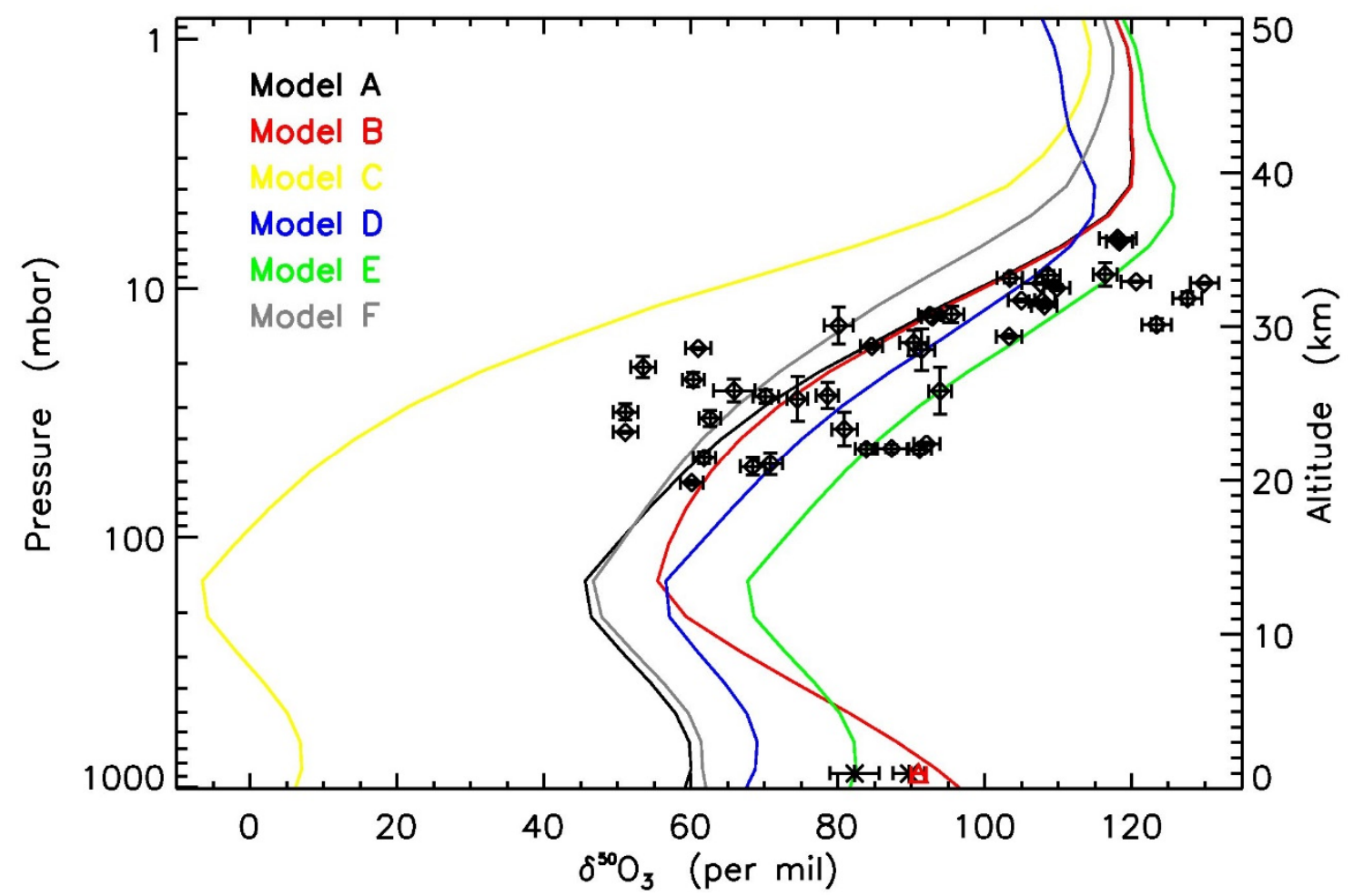

Figure 1. $\delta^{50} \mathrm{O}_{3}$ (referenced to atmospheric $\mathrm{O}_{2}$ ) calculated using the same model atmosphere profile as that in Liang et al. [5]. Pressure and temperature dependences in $\mathrm{O}_{3}$ isotopic fractionations are taken into account, and the isotopic fractionation for ozone photolysis in the Chappuis band is scaled from ${ }^{18} \mathrm{O}^{18} \mathrm{O}^{18} \mathrm{O}$ (see text). See Table 1 for model differences. Diamonds are balloon-borne mass spectrometer measurements [3]. The asterisks [8] and triangle [2] are the near-surface measurements. The error bars in the atmospheric measurements are for $1-\sigma$. The experimental data variations represent spatial and temporal differences at which the data were taken. 


\section{Temperature Variation}

The isotopic fractionation by photolysis has a weak temperature dependence $[5,38]$. The temperature dependence of the isotopic value $(\delta)$ of ozone is primarily from the formation of ozone. The temperature sensitivity for $\delta$ in ozone formation is $\sim 0.3 \% \mathrm{~K}^{-1}$, and the value becomes $\sim 0.6 \% \mathrm{~K}^{-1}$ after considering $\mathrm{O}+\mathrm{O}_{2}$ isotopic exchange processes [39]. To bring the model $\delta$-values of ozone into better agreement with observations requires a reduction of $\sim 15-20 \mathrm{~K}$ in the climatological temperature profile (Model D vs. Model E). To refine previous calculations $[5,6,22]$, we examine the effect by replacing the temperature profile used in previous studies with more realistic daily and 6-hourly temperature profiles from the National Centers for Environmental Prediction-Department of Energy Reanalysis 2 (NCEP2) [40].

The zero-point-energy theory for estimating the isotopic fractionation of ozone in the Chappuis band is assumed, as in Liang et al. [5]. Combining the kinetic fractionation processes in the formation and photolysis of ozone, the calculated $\delta^{49} \mathrm{O}_{3}$ and $\delta^{50} \mathrm{O}_{3}$ remain $>10 \%$ larger than the measurements (Figure 2). Here, we update previous calculations to include pressure dependence, which reduces $\delta$-values at higher pressures. By incorporating NCEP2 daily temperature into the model, a better agreement is achieved. However, there is a difference between the observed temperature (in situ measurements and NCEP2 data) and the temperature that is required to reproduce the observed values of $\delta^{49} \mathrm{O}_{3}$ and $\delta^{50} \mathrm{O}_{3}$ (Table 1 and Figure 3). The in situ measured temperature tends to be higher than the climatological and NCEP2 daily and 6-hourly temperature.

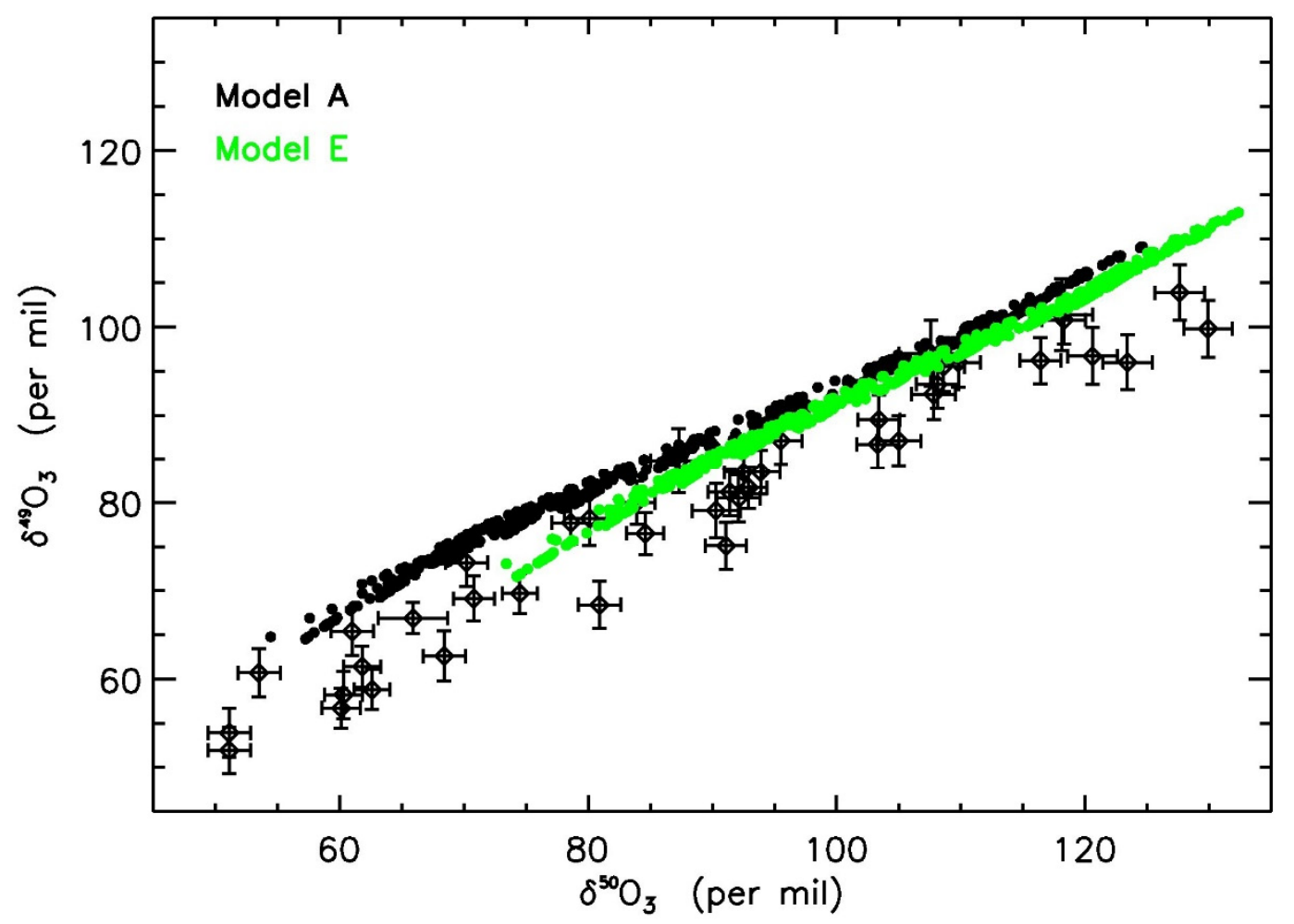

Figure 2. Three-isotope plot of $\mathrm{O}_{3}$, where the variations caused by sampling in different seasons and localities are largely reduced. Diamonds are balloon-borne mass spectrometer measurements [3]. The error bars in the atmospheric measurements are for 1- $\sigma$. The 2-D model results, calculated by Models A and E, at the same altitudes and seasons as the atmospheric measurements, are shown by the solid circles. 


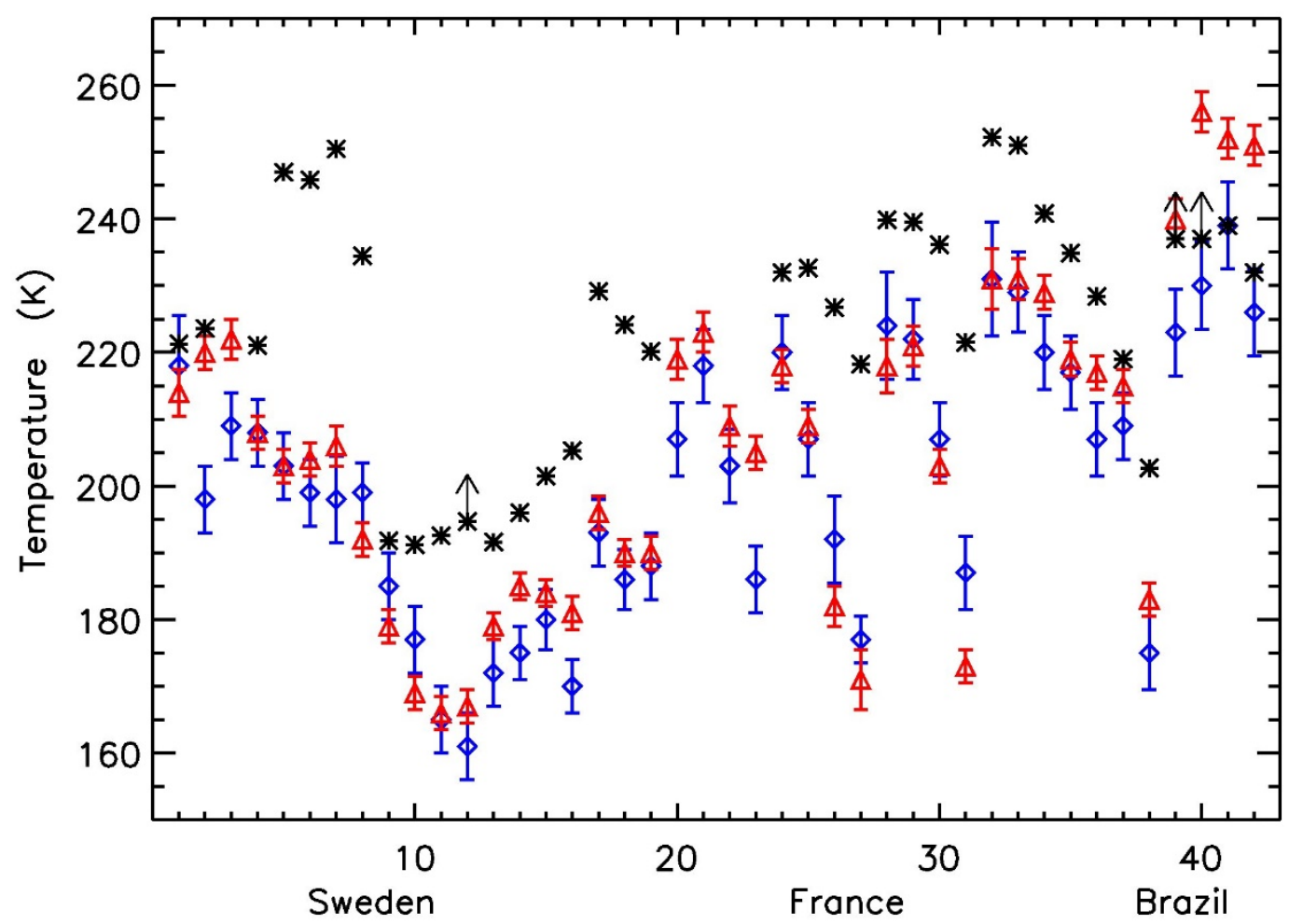

Figure 3. Values are from Table 2 for Sweden (horizontal number index 1 to 16), France (17 to 35), and Brazil (36 to 42 ). $\mathrm{T}\left(\delta^{49} \mathrm{O}_{3}\right)$ and $\mathrm{T}\left(\delta^{50} \mathrm{O}_{3}\right)$ are shown by the diamonds and triangles, respectively. The in situ measured $\mathrm{T}_{\text {in situ }}$ is represented by the asterisks.

Table 2. Model inferred and measured temperatures for the sites.

\begin{tabular}{|c|c|c|c|c|c|c|c|}
\hline Number & Date & Height & $\mathrm{T}\left(\delta^{49} \mathrm{O}_{3}\right)$ & $\mathrm{T}\left(\delta^{50} \mathrm{O}_{3}\right)$ & $\mathrm{T}_{\mathrm{clim}}$ & $\mathrm{T}_{\text {in situ }}$ & $\mathbf{T}_{\text {NCEP }}$ \\
\hline \multicolumn{8}{|l|}{ Sweden } \\
\hline 1 & 10 May 1998 & 22.1 & $218 \pm 15$ & $214 \pm 7$ & 218 & 221.3 & 222 \\
\hline 2 & 10 May 1998 & 22 & $198 \pm 10$ & $220 \pm 5$ & 218 & 223.59 & 222 \\
\hline 3 & 10 May 1998 & 22.4 & $209 \pm 10$ & $222 \pm 6$ & 218 & $\mathrm{~N} / \mathrm{A}$ & 222.1 \\
\hline 4 & 10 May 1998 & 22.1 & $208 \pm 10$ & $208 \pm 5$ & 218 & 221.08 & 222 \\
\hline 5 & 3 May 1999 & 30.8 & $203 \pm 10$ & $203 \pm 5$ & 229 & 247 & 230 \\
\hline 6 & 3 May 1999 & 30.6 & $199 \pm 10$ & $204 \pm 5$ & 229 & 245.85 & 229.8 \\
\hline 7 & 3 May 1999 & 29 & $198 \pm 13$ & $206 \pm 6$ & 226 & 250.5 & 226.5 \\
\hline 8 & 3 May 1999 & 25.5 & $199 \pm 9$ & $192 \pm 5$ & 221 & 234.45 & 220.7 \\
\hline 9 & 3 December 2001 & 28.6 & $185 \pm 10$ & $179 \pm 5$ & 201 & 191.8 & 205.8 \\
\hline 10 & 3 December 2001 & 27.4 & $177 \pm 10$ & $169 \pm 5$ & 201 & 191.2 & 205.7 \\
\hline 11 & 3 December 2001 & 24.5 & $165 \pm 10$ & $166 \pm 5$ & 201 & 192.55 & 206.3 \\
\hline 12 & 3 December 2001 & 23.2 & $161 \pm 10$ & $167 \pm 5$ & 202 & $>194.7$ & 207 \\
\hline 13 & 28 November 2002 & 26.6 & $172 \pm 10$ & $179 \pm 4$ & 198 & 191.6 & 192.4 \\
\hline 14 & 28 November 2002 & 24.1 & $175 \pm 8$ & $185 \pm 4$ & 199 & 196 & 195 \\
\hline 15 & 28 November 2002 & 21.5 & $180 \pm 9$ & $184 \pm 4$ & 204 & 201.5 & 199.7 \\
\hline 16 & 28 November 2002 & 19.8 & $170 \pm 8$ & $181 \pm 5$ & 208 & 205.3 & 203.2 \\
\hline
\end{tabular}


Table 2. Cont.

\begin{tabular}{|c|c|c|c|c|c|c|c|}
\hline Number & Date & Height & $\mathrm{T}\left(\delta^{49} \mathrm{O}_{3}\right)$ & $\mathrm{T}\left(\delta^{50} \mathrm{O}_{3}\right)$ & $\mathbf{T}_{\text {clim }}$ & $\mathbf{T}_{\text {in situ }}$ & $\mathrm{T}_{\mathrm{NCEP}}$ \\
\hline \multicolumn{8}{|l|}{ France } \\
\hline 17 & 3 October 1998 & 28.7 & $193 \pm 10$ & $196 \pm 5$ & 222 & 229.15 & 223.1 \\
\hline 18 & 3 October 1998 & 25.3 & $186 \pm 9$ & $190 \pm 4$ & 216 & 224.15 & 218.7 \\
\hline 19 & 3 October 1998 & 21.1 & $188 \pm 10$ & $190 \pm 5$ & 214 & 220.15 & 215.2 \\
\hline 20 & 11 October 1999 & 31.7 & $207 \pm 11$ & $219 \pm 6$ & 223 & $\mathrm{~N} / \mathrm{A}$ & 225.4 \\
\hline 21 & 11 October 1999 & 31.6 & $218 \pm 11$ & $223 \pm 6$ & 223 & $\mathrm{~N} / \mathrm{A}$ & 225.3 \\
\hline 22 & 11 October 1999 & 28.5 & $203 \pm 11$ & $209 \pm 6$ & 221 & $\mathrm{~N} / \mathrm{A}$ & 219.9 \\
\hline 23 & 11 October 1999 & 23.4 & $186 \pm 10$ & $205 \pm 5$ & 216 & $\mathrm{~N} / \mathrm{A}$ & 212.8 \\
\hline 24 & 4 October 2000 & 33.4 & $220 \pm 11$ & $218 \pm 5$ & 226 & 232 & 230.4 \\
\hline 25 & 4 October 2000 & 33.1 & $207 \pm 11$ & $209 \pm 5$ & 226 & 232.63 & 230 \\
\hline 26 & 4 October 2000 & 30.1 & $192 \pm 13$ & $182 \pm 6$ & 222 & 226.73 & 223.7 \\
\hline 27 & 4 October 2000 & 25.9 & $177 \pm 7$ & $171 \pm 9$ & 217 & 218.25 & 215.8 \\
\hline 28 & 11 May 2001 & 32.8 & $224 \pm 16$ & $218 \pm 8$ & 231 & 239.86 & 238.7 \\
\hline 29 & 11 May 2001 & 32.5 & $222 \pm 12$ & $221 \pm 6$ & 231 & 239.55 & 238 \\
\hline 30 & 11 May 2001 & 30.8 & $207 \pm 11$ & $203 \pm 5$ & 229 & 236.15 & 233.5 \\
\hline 31 & 11 May 2001 & 25.5 & $187 \pm 11$ & $173 \pm 5$ & 220 & 221.5 & 220.4 \\
\hline 32 & 25 April 2002 & 35.8 & $231 \pm 17$ & $231 \pm 9$ & 233 & 252.25 & 242.8 \\
\hline 33 & 25 April 2002 & 35.5 & $229 \pm 12$ & $231 \pm 6$ & 233 & 251 & 242.2 \\
\hline 34 & 25 April 2002 & 33.4 & $220 \pm 11$ & $229 \pm 5$ & 233 & 240.81 & 237.2 \\
\hline 35 & 25 April 2002 & 31.4 & $217 \pm 11$ & $219 \pm 5$ & 230 & 234.89 & 232.4 \\
\hline \multicolumn{8}{|l|}{ Brazil } \\
\hline 36 & 29-30 November 2004 & 29.4 & $207 \pm 11$ & $217 \pm 5$ & 224 & 228.4 & 227.5 \\
\hline 37 & 29-30 November 2004 & 25.8 & $209 \pm 10$ & $215 \pm 5$ & 216 & 219 & 220 \\
\hline 38 & 29-30 November 2004 & 20.9 & $175 \pm 11$ & $183 \pm 5$ & 207 & 202.7 & 206.6 \\
\hline 39 & 4 June 2005 & 32.9 & $223 \pm 13$ & $240 \pm 6$ & 230 & $>237$ & 232.4 \\
\hline 40 & 4 June 2005 & 32.8 & $230 \pm 13$ & $256 \pm 6$ & 230 & $>237$ & 232.3 \\
\hline 41 & 4 June 2005 & 31.9 & $239 \pm 13$ & $252 \pm 6$ & 229 & 239 & 230.8 \\
\hline 42 & 4 June 2005 & 30.1 & $226 \pm 13$ & $251 \pm 6$ & 227 & 232 & 228.2 \\
\hline
\end{tabular}

Note: Height and temperature are in units of $\mathrm{km}$ and Kelvin, respectively. $\mathrm{T}\left(\delta^{49} \mathrm{O}_{3}\right)$ and $\mathrm{T}\left(\delta^{50} \mathrm{O}_{3}\right)$ are the model inferred temperatures from the observed $\delta^{49} \mathrm{O}_{3}$ and $\delta^{50} \mathrm{O}_{3}$ [3]; the low-pressure limit is assumed. $\mathrm{T}_{\text {clim }}, \mathrm{T}_{\text {in situ, and }} \mathrm{T}_{\mathrm{NCEP}}$ are the climatological, in situ measured, and NCEP2 reanalysis daily temperatures, respectively. Zero-point-energy theory for estimating the ozone fractionation in the Chappuis band is applied.

\section{Chappuis Band Photolysis}

Photolysis of ozone occurs primarily in the Hartley and Huggins bands in the UV and Chappuis bands at longer wavelengths (450-850 nm). Chappuis band photolysis dominates for altitudes $<35 \mathrm{~km}$ and could deplete heavy ozone [5,31,32,41-43]. Due to limited photolytic data for major isotopolocules of ozone in the visible band [31,32,44], we followed typical theories to estimate the fractionation. They are either zero-point-energy theory [29] or modified zero-point-energy theory $[27,28]$. The latter is applied to ozone in the Hartley and Huggins bands and turns out to be reliable [5]. Both theories predict similar and small but positive fractionation in the Chappuis band, and they cannot explain the observed data for ${ }^{18} \mathrm{O}^{18} \mathrm{O}^{18} \mathrm{O}[42,43]$ and ${ }^{49} \mathrm{O}_{3}$ and ${ }^{50} \mathrm{O}_{3}[31,32,44]$. An alternative way is to scale the fractionation from ${ }^{18} \mathrm{O}^{18} \mathrm{O}^{18} \mathrm{O}$, and the results obtained by assuming two approaches are shown in Figure 4. One way is to assume that the fractionation is linearly proportional to 
the difference of their zero-point-energies (dashed curves). This approach overestimates the effect from the Chappuis band (see Model C). A factor of four reduction (solid curves) in the zero-point-energy shift provides a better fit to the observations (Model A). However, both produce near-surface ozone isotopically too light compared with the observations (see Figure 1). This discrepancy could be explained by $\mathrm{NO}+\mathrm{O}_{3}$ reaction that enhances the isotopic composition of ozone [45], because the measurements were taken in urban areas, instead of a clean atmosphere, where the Chapman chemistry is not valid. Thus, the isotopic compositions of near-surface ozone are affected by both the photolysis in the Chappuis band and the reaction with NO.

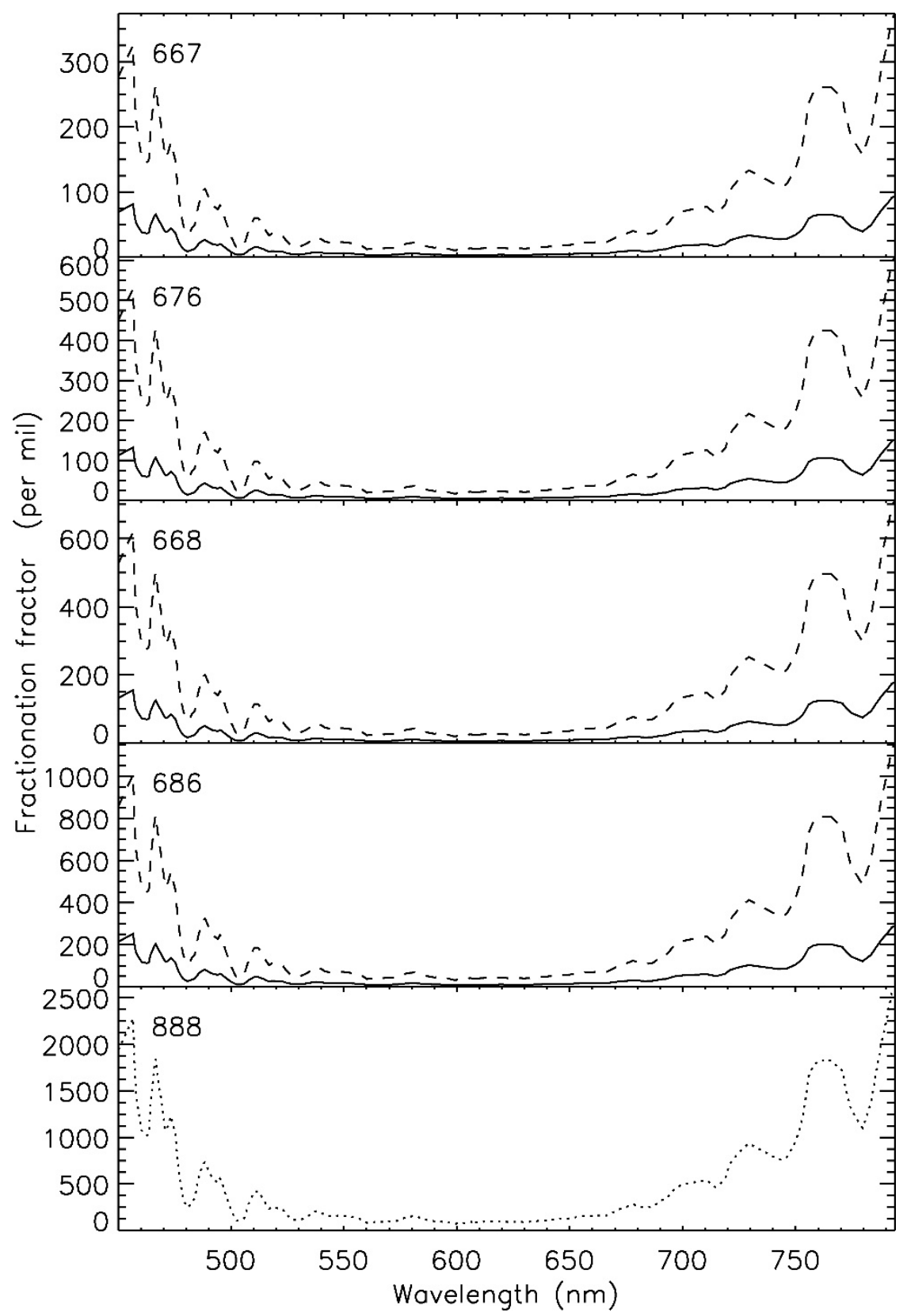

Figure 4. Calculated fractionations for ${ }^{16} \mathrm{O}^{16} \mathrm{O}^{17} \mathrm{O}(667),{ }^{16} \mathrm{O}^{17} \mathrm{O}^{16} \mathrm{O}(676),{ }^{16} \mathrm{O}^{16} \mathrm{O}^{18} \mathrm{O}(668)$, and ${ }^{16} \mathrm{O}^{18} \mathrm{O}^{16} \mathrm{O}$ (686). The solid and dashed are the fractionation factors used in Model A and Model C, respectively. See text for details. The laboratory determined fractionation for ${ }^{18} \mathrm{O}^{18} \mathrm{O}^{18} \mathrm{O}(888$; dotted curve) is taken from Anderson et al. [39], who measured at conditions of $\sim 40$ torr with $0.46 \mathrm{~m}$ pathlength and $2.3 \mathrm{~nm}$ bandwidth. 
To verify the photolytic calculation shown above, we compare the model adopted fractionations with limited data. The result is summarized in Figure 5; we compare with the data from Huang et al. [32] only, because the fractionation factors were obtained at well-defined wavelengths. We see that at the four wavelengths of the measurements, the model needed fractionations deviate significantly from the laboratory data, suggesting hitherto unknown processes in affecting the photolytic process of ozone. We do not have the data at other wavelengths. Thus, the photolysis-induced isotopic fractionation in the Chappuis band remains a solution to the model-observation discrepancy mentioned above. This calls for an urgent need for laboratory measurements at other wavelengths in the Chappuis band, essential for tropospheric chemistry research.

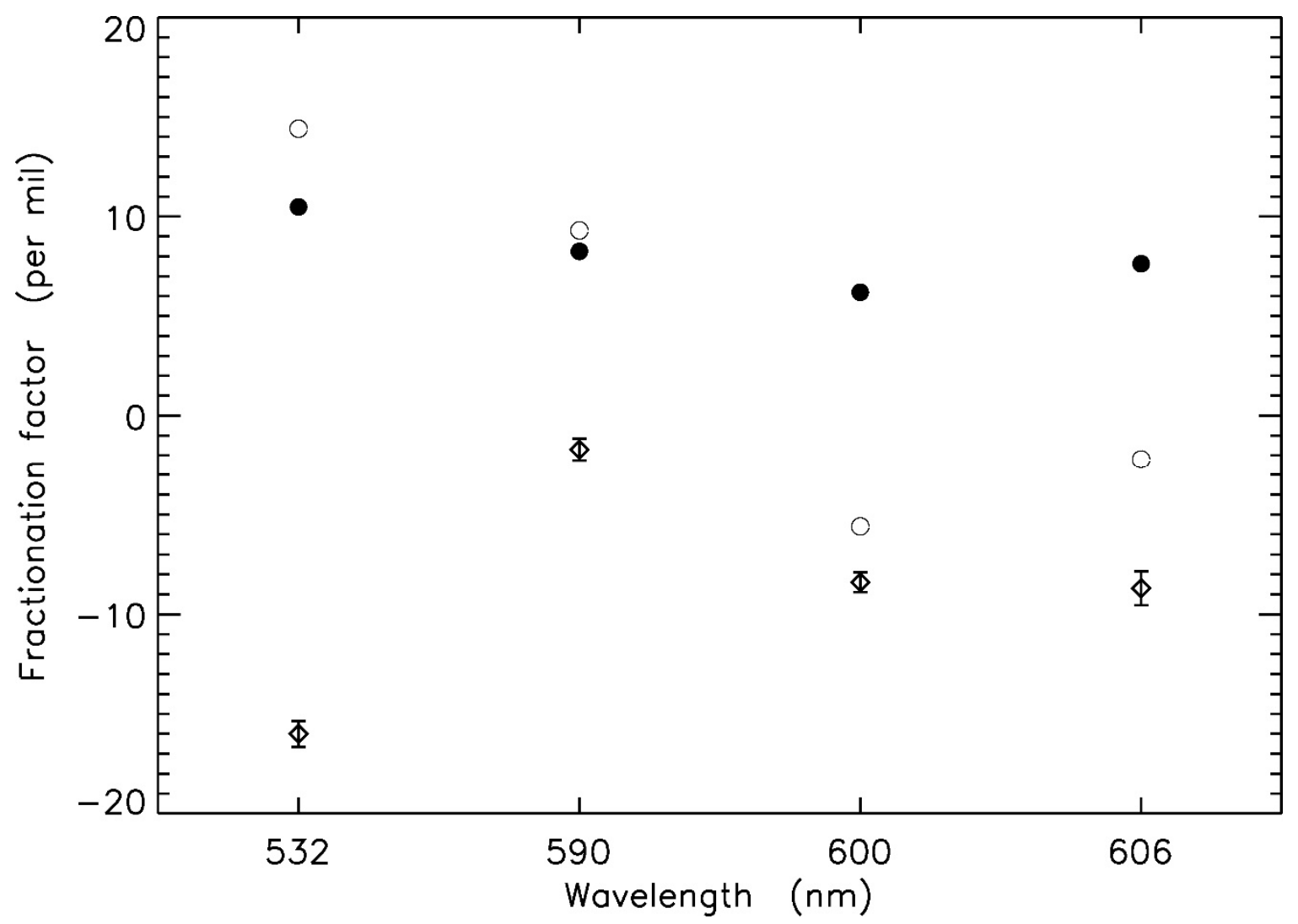

Figure 5. Comparison of the model fractionations (Model A: solid circles; Model D: open circles) and laboratory measurements (diamonds, with 1- $\sigma$ measurement errors overplotted; see Huang et al. [32]) in the Chappuis band.

The solar radiation at visible wavelengths is affected by multiple scattering [46]. Hence, the photolysis in the Chappuis band in the stratosphere can be significantly enhanced by clouds in the troposphere. We perform an aerosol and cloud scattering calculation, based on Discrete Ordinates Radiative Transfer Program for a Multi-Layered Plane-Parallel Medium [47], by introducing a bright cloud layer between $900-1200 \mathrm{~m}$, with single scattering albedo 0.999 and asymmetry factor 0.85 . The typical cloud optical depth at $300 \mathrm{~nm}$ is $\sim 18.6$, compared to that due to ozone absorption ( 3.6) and Rayleigh extinction ( 1.3). Figure 1 demonstrates an example of enhancing the photolysis rate coefficient in the Chappuis bands (Model F). Indeed, the model helps reduce the delta values in the lower stratosphere (cf. Model A). We note that cloud multiple scattering is not a solution to the aforementioned model imperfection. Instead, the role of scattering is to amplify the isotopic fractionation in the Chappuis band. 


\section{Discussion and Conclusions}

It is known that the isotopic composition of $\mathrm{O}_{3}$ is influenced by its formation and photolysis. Here, we focus our analysis and make comparison with ozone measurements from mass spectrometry, because of its analytical precision. Remote sensing data [1,9-12], though retrieved at reduced precision, remain potentially useful, especially when retrieval algorithms are improved, because the technique provides good spatial and temporal coverages that mass spectrometry cannot. Furthermore, spectroscopic methods distinguish symmetric from asymmetric ozone molecules, essential for identifying missing processes, if they exist, in affecting the isotope composition of ozone in the atmosphere, because of their difference in, for example, altitude dependence [5].

Three factors affect the isotopic composition: pressure, temperature, and photolysis. The in situ measured $\delta^{49} \mathrm{O}_{3}$ and $\delta^{49} \mathrm{O}_{3}$ values between 20 and $35 \mathrm{~km}$ range from 50 to $130 \%$. Large discrepancies between the measurements and previous models are found (Figures 1 and 2 and Table 1). To account for the observed $\delta^{49} \mathrm{O}_{3}$ and $\delta^{50} \mathrm{O}_{3}$, their temperature and pressure dependences are examined. The formation of $\mathrm{O}_{3}$ at higher pressures reduces the abundance of heavy ozone. However, the pressure in the regions of interest $(>20 \mathrm{~km})$ is less than $100 \mathrm{mbar}$, and the modification is about $-5 \%$ or less, compared with the low-pressure calculation (Figure 1). Hence, the pressure dependence as a source of the discrepancy seen for the data in the stratosphere is insufficient. The isotopic value of atmospheric $\mathrm{O}_{3}$ has relatively weak temperature dependence $\left(\sim 0.6 \% \mathrm{~K}^{-1}\right)$, and the required temperature to explain the data differs significantly from the reanalysis and in situ temperatures (Table 1). Therefore, the temperature mechanism becomes less plausible. This leaves attenuated dissociative photon flux as the only mechanism, though hitherto unknown mechanisms in fractionating the isotopic composition of $\mathrm{O}_{3}$ in the atmosphere are not ruled out. As the model values are biased to be too high compared with the measurements, the photolysis in the Chappuis band could help reduce the deviation if the rate coefficient or the isotopic fractionation in this band is enhanced. Calculations of multiple photon scattering that affect dissociative photon distributions are insufficient to reduce the isotopic composition of ozone. Directly tuning the fractionation factor in the Chappuis band provides a better explanation. New laboratory measurements, especially the Chappuis band, are needed to quantify the processes that affect the isotopic composition of ozone in the atmosphere.

The isotopic signature in $\mathrm{O}_{3}$ can be transferred readily to other trace species such as the hydroxyl radical, nitrate, and nitrite $[7,18,19,26,48]$. Take $\mathrm{NO}_{\mathrm{x}}\left(=\mathrm{NO}+\mathrm{NO}_{2}\right)$ as an example. The transfer of isotope anomaly from $\mathrm{O}_{3}$ to nitrate and nitrite is due to the following reactions:

$$
\begin{gathered}
\mathrm{NO}_{2}+\mathrm{h} v \rightarrow \mathrm{NO}+\mathrm{O} \\
\mathrm{O}+\mathrm{O}_{2}+\mathrm{M} \rightarrow \mathrm{O}_{3}+\mathrm{M} \\
\mathrm{NO}+\mathrm{O}_{3} \rightarrow \mathrm{NO}_{2}+\mathrm{O}_{2} .
\end{gathered}
$$

The subsequent chemical reactions with $\mathrm{O}_{3}, \mathrm{OH}$, and $\mathrm{H}_{2} \mathrm{O}$ produce nitrates and nitrites containing an isotope signature from $\mathrm{O}_{3}$. Similar transformation also applies to $\mathrm{OH}$ through

$$
\begin{aligned}
& \mathrm{O}_{3}+\mathrm{h} v \rightarrow \mathrm{O}\left({ }^{1} \mathrm{D}\right)+\mathrm{O}_{2} \\
& \mathrm{O}\left({ }^{1} \mathrm{D}\right)+\mathrm{H}_{2} \mathrm{O} \rightarrow 2 \mathrm{OH} .
\end{aligned}
$$

Hence, the anomalous isotope signature in oxygen provides useful tools for tracing pollution chemistry because $\mathrm{O}_{3}$ is central to tropospheric chemistry $[49,50]$. In addition to the present-day atmosphere, the composition of paleo-atmospheres could also be constrained by the unique isotope anomaly in oxygen, such as the level of carbon dioxide [51]. The applicability requires the knowledge of processes that affect the isotopic composition of ozone, which remains unsatisfactory. Photolysis in the Chappuis band, in particular, deserves further investigation, because it is essential in affecting the isotopic composition of ozone. 
Author Contributions: Conceptualization, M.-C.L. and Y.L.Y.; methodology, M.-C.L., Y.-C.C., Y.-Q.G., X.Z. and Y.L.Y.; validation, M.-C.L.; formal analysis, M.-C.L., Y.-C.C. and X.Z.; investigation, M.-C.L., Y.-C.C. and X.Z.; data curation, M.-C.L., Y.-C.C. and X.Z.; writing-original draft preparation, M.-C.L.; writing-review and editing, M.-C.L., Y.-C.C., X.Z. and Y.L.Y.; visualization, M.-C.L., Y.-C.C. and X.Z.; funding acquisition, M.-C.L. All authors have read and agreed to the published version of the manuscript.

Funding: This research was supported in part by MOST Grants 108-2111-M-001-011-MY3, 109-2111M-001-009-, 110-2111-M-001-012-, and 110-2111-M-001-015 to Academia Sinica and an Academia Sinica Grant AS-IA-109-M03. X.Z. was supported by National Science Foundation Grant AGS1901126 to the University of California, Santa Cruz. Y.L.Y. was supported in part an NAI Virtual Planetary Laboratory Grant from the University of Washington to the Jet Propulsion Laboratory and California Institute of Technology.

Institutional Review Board Statement: Not applicable.

Informed Consent Statement: Not applicable.

Data Availability Statement: The data used in the paper are either provided in the table or taken from the published papers refereed.

Acknowledgments: We thank D. Krankowsky for providing the in situ measured temperatures.

Conflicts of Interest: The authors declare no conflict of interest.

\section{References}

1. Irion, F.W.; Gunson, M.R.; Rinsland, C.P.; Yung, Y.L.; Abrams, M.C.; Chang, A.Y.; Goldman, A. Heavy ozone enrichments from ATMOS infrared solar spectra. Geophys. Res. Lett. 1996, 23, 2377-2380. [CrossRef]

2. Krankowsky, D.; Bartecki, F.; Klees, G.G.; Mauersberger, K.; Schellenbach, K.; Stehr, J. Measurement of Heavy Isotope Enrichment in Tropospheric Ozone. Geophys. Res. Lett. 1995, 22, 1713-1716. [CrossRef]

3. Krankowsky, D.; Lammerzahl, P.; Mauersberger, K.; Janssen, C.; Tuzson, B.; Rockmann, T. Stratospheric ozone isotope fractionations derived from collected samples. J. Geophys. Res. Atmos. 2007, 112, D08301. [CrossRef]

4. Mauersberger, K. Measurement of Heavy Ozone in the Stratosphere. Geophys. Res. Lett. 1981, 8, 935-937. [CrossRef]

5. $\quad$ Liang, M.C.; Irion, F.W.; Weibel, J.D.; Miller, C.E.; Blake, G.A.; Yung, Y.L. Isotopic composition of stratospheric ozone. J. Geophys. Res. Atmos. 2006, 111, D02302. [CrossRef]

6. Liang, M.C.; Yung, Y.L. Sources of the oxygen isotopic anomaly in atmospheric $\mathrm{N}_{2}$ O. J. Geophys. Res. Atmos. 2007, 112 , D13307. [CrossRef]

7. Thiemens, M.H. History and applications of mass-independent isotope effects. Annu. Rev. Earth Planet. Sci. 2006, 34, 217-262. [CrossRef]

8. Johnston, J.C.; Thiemens, M.H. The isotopic composition of tropospheric ozone in three environments. J. Geophys. Res. Atmos. 1997, 102, 25395-25404. [CrossRef]

9. Haverd, V.; Toon, G.C.; Griffith, D.W. Evidence for altitude-dependent photolysis-induced $18 \mathrm{O}$ isotopic fractionation in stratospheric ozone. Geophys. Res. Lett. 2005, 32, L22808. [CrossRef]

10. Jonkheid, B.; Röckmann, T.; Glatthor, N.; Janssen, C.; Stiller, G.; Clarmann, T.V. Retrievals of heavy ozone with MIPAS. Atmos. Meas. Tech. 2016, 9, 6069-6079. [CrossRef]

11. Kasai, Y.J.; Urban, J.; Takahashi, C.; Hoshino, S.; Takahashi, K.; Inatani, J.; Shiotani, M.; Masuko, H. Stratospheric ozone isotope enrichment studied by submillimeter wave heterodyne radiometry: The observation capabilities of SMILES. IEEE Trans. Geosci. Remote Sens. 2006, 44, 676-693. [CrossRef]

12. Fernando, A.M.; Bernath, P.F.; Boone, C.D. Ozone isotopologue measurements from the Atmospheric Chemistry Experiment (ACE). J. Quant. Spectrosc. Radiat. Transf. 2019, 238, 106547. [CrossRef]

13. Bao, H.; Thiemens, M.H.; Farquhar, J.; Campbell, D.A.; Lee, C.C.; Heine, K.; Loope, D.B. Anomalous $17 \mathrm{O}$ compositions in massive sulphate deposits on the Earth. Nature 2000, 406, 176-178. [CrossRef]

14. Boering, K.A.; Jackson, T.; Hoag, K.J.; Cole, A.S.; Perri, M.J.; Thiemens, M.; Atlas, E. Observations of the anomalous oxygen isotopic composition of carbon dioxide in the lower stratosphere and the flux of the anomaly to the troposphere. Geophys. Res. Lett. 2004, 31, L03109. [CrossRef]

15. Cliff, S.S.; Thiemens, M.H. The $18 \mathrm{O} / 16 \mathrm{O}$ and $17 \mathrm{O} / 16 \mathrm{O}$ ratios in atmospheric nitrous oxide: A mass-independent anomaly. Science 1997, 278, 1774-1776. [CrossRef]

16. Lammerzahl, P.; Rockmann, T.; Brenninkmeijer, C.A.M.; Krankowsky, D.; Mauersberger, K. Oxygen isotope composition of stratospheric carbon dioxide. Geophys. Res. Lett. 2002, 29, 1582. [CrossRef]

17. Liang, M.C.; Blake, G.A.; Lewis, B.R.; Yung, Y.L. Oxygen isotopic composition of carbon dioxide in the middle atmosphere. Proc. Natl. Acad. Sci. USA 2007, 104, 21-25. [CrossRef] 
18. Michalski, G.; Scott, Z.; Kabiling, M.; Thiemens, M.H. First measurements and modeling of Delta O-17 in atmospheric nitrate. Geophys. Res. Lett. 2003, 30, 1870. [CrossRef]

19. Morin, S.; Savarino, J.; Frey, M.M.; Yan, N.; Bekki, S.; Bottenheim, J.W.; Martins, J.M. Tracing the origin and fate of NO $\mathrm{N}_{\mathrm{x}}$ in the Arctic atmosphere using stable isotopes in nitrate. Science 2008, 322, 730-732. [CrossRef]

20. Thiemens, M.H.; Jackson, T.; Zipf, E.C.; Erdman, P.W.; Vanegmond, C. Carbon-Dioxide and Oxygen-Isotope Anomalies in the Mesosphere and Stratosphere. Science 1995, 270, 969-972. [CrossRef]

21. Lyons, J.R. Transfer of mass-independent fractionation in ozone to other oxygen-containing radicals in the atmosphere. Geophys. Res. Lett. 2001, 28, 3231-3234. [CrossRef]

22. Liang, M.C.; Blake, G.A.; Yung, Y.L. Seasonal cycle of $\mathrm{C}^{16} \mathrm{O}^{16} \mathrm{O}, \mathrm{C}^{16} \mathrm{O}^{17} \mathrm{O}$, and $\mathrm{C}^{16} \mathrm{O}^{18} \mathrm{O}$ in the middle atmosphere: Implications for mesospheric dynamics and biogeochemical sources and sinks of $\mathrm{CO}_{2}$. J. Geophys. Res. Atmos. 2008, 113, D12305. [CrossRef]

23. Wiegel, A.A.; Cole, A.S.; Hoag, K.J.; Atlas, E.L.; Schauffler, S.M.; Boering, K.A. Unexpected variations in the triple oxygen isotope composition of stratospheric carbon dioxide. Proc. Natl. Acad. Sci. USA 2013, 110, 17680-17685. [CrossRef]

24. Liang, M.C.; Mahata, S.; Laskar, A.H.; Thiemens, M.H.; Newman, S. Oxygen isotope anomaly in tropospheric $\mathrm{CO}_{2}$ and implications for $\mathrm{CO}_{2}$ residence time in the atmosphere and gross primary productivity. Sci. Rep. 2017, 7, 13180. [CrossRef]

25. Koren, G.; Schneider, L.; van der Velde, I.R.; van Schaik, E.; Gromov, S.S.; Adnew, G.A.; Mrozek, D.J.; Hofmann, M.E.; Liang, M.C.; Mahata, S. Global 3D Simulations of the Triple Oxygen Isotope Signature $\Delta^{17} \mathrm{O}$ in Atmospheric $\mathrm{CO}_{2}$. J. Geophys. Res. Atmos. 2018, $145,8808-8836$.

26. Guha, T.; Lin, C.T.; Bhattacharya, S.K.; Mahajan, A.S.; Ou-Yang, C.F.; Lan, Y.P.; Hsu, S.C.; Liang, M.C. Isotopic ratios of nitrate in aerosol samples from Mt. Lulin, a high-altitude station in Central Taiwan. Atmos. Environ. 2017, 154, 53-69. [CrossRef]

27. Liang, M.C.; Blake, G.A.; Yung, Y.L. A semianalytic model for photo-induced isotopic fractionation in simple molecules. J. Geophys. Res. Atmos. 2004, 109, D10308. [CrossRef]

28. Blake, G.A.; Liang, M.C.; Morgan, C.G.; Yung, Y.L. A Born-Oppenheimer photolysis model of $\mathrm{N}_{2} \mathrm{O}$ fractionation. Geophys. Res. Lett. 2003, 30, 1656. [CrossRef]

29. Yung, Y.L.; Miller, C.E. Isotopic fractionation of stratospheric nitrous oxide. Science 1997, 278, 1778-1780. [CrossRef]

30. Früchtl, M.; Janssen, C.; Röckmann, T. Experimental study on isotope fractionation effects in visible photolysis of $\mathrm{O}_{3}$ and in the $\mathrm{O}+\mathrm{O}_{3}$ odd oxygen sink reaction. J. Geophys. Res. Atmos. 2015, 120, 4398-4416. [CrossRef]

31. Früchtl, M.; Janssen, C.; Taraborrelli, D.; Gromov, S.; Röckmann, T. Wavelength-dependent isotope fractionation in visible light $\mathrm{O}_{3}$ photolysis and atmospheric implications. Geophys. Res. Lett. 2015, 42, 8711-8718. [CrossRef]

32. Huang, C.H.; Bhattacharya, S.K.; Hsieh, Z.M.; Chen, Y.J.; Yih, T.S.; Liang, M.C. Isotopic Fractionation in Photolysis of Ozone in the Hartley and Chappuis Bands. Earth Space Sci. 2019, 6, 752-773. [CrossRef]

33. Guenther, J.; Erbacher, B.; Krankowsky, D.; Mauersberger, K. Pressure dependence of two relative ozone formation rate coefficients. Chem. Phys. Lett. 1999, 306, 209-213. [CrossRef]

34. Gao, Y.Q.; Marcus, R.A. An approximate theory of the ozone isotopic effects: Rate constant ratios and pressure dependence. J. Chem. Phys. 2007, 127, 244316. [CrossRef] [PubMed]

35. Gao, Y.Q.; Marcus, R.A. Strange and unconventional isotope effects in ozone formation. Science 2001, 293, 259-263. [CrossRef]

36. Gao, Y.Q.; Marcus, R.A. On the theory of the strange and unconventional isotopic effects in ozone formation. J. Chem. Phys. 2002, 116, 137-154. [CrossRef]

37. Marcus, R.A.; Gao, Y.Q. Pressure effects on bimolecular recombination and unimolecular dissociation reactions. J. Chem. Phys. 2001, 114, 9807-9812. [CrossRef]

38. Kaiser, J.; Rockmann, T.; Brenninkmeijer, C.A.M. Temperature dependence of isotope fractionation in $\mathrm{N}_{2} \mathrm{O}$ photolysis. Phys. Chem. Chem. Phys. 2002, 4, 4420-4430. [CrossRef]

39. Morton, J.; Barnes, J.; Schueler, B.; Mauersberger, K. Laboratory Studies of Heavy Ozone. J. Geophys. Res. Atmos. 1990, 95, 901-907. [CrossRef]

40. Kistler, R.; Kalnay, E.; Collins, W.; Saha, S.; White, G.; Woollen, J.; Chelliah, M.; Ebisuzaki, W.; Kanamitsu, M.; Kousky, V.; et al. The NCEP-NCAR 50-year reanalysis: Monthly means CD-ROM and documentation. Bull. Am. Meteorol. Soc. 2001, 82, 247-267. [CrossRef]

41. Miller, C.E.; Onorato, R.M.; Liang, M.C.; Yung, Y.L. Extraordinary isotopic fractionation in ozone photolysis. Geophys. Res. Lett. 2005, 32, L14814. [CrossRef]

42. Anderson, S.M.; Maeder, J.; Mauersberger, K. Effect of Isotopic-Substitution on the Visible Absorption-Spectrum of Ozone. J. Chem. Phys. 1991, 94, 6351-6357. [CrossRef]

43. Anderson, S.M.; Mauersberger, K. Ozone Absorption-Spectroscopy in Search of Low-Lying Electronic States. J. Geophys. Res. Atmos. 1995, 100, 3033-3048. [CrossRef]

44. Wen, J.; Thiemens, M.H. Experimental and Theoretical-Study of Isotope Effects on Ozone Decomposition. J. Geophys. Res. Atmos. 1991, 96, 10911-10921. [CrossRef]

45. Chakraborty, S.; Chakraborty, S. Isotopic fractionation of the $\mathrm{O}_{3}$-nitric oxide reaction. Curr. Sci. 2003, 85, 1210-1212.

46. Liao, H.; Yung, Y.L.; Seinfeld, J.H. Effects of aerosols on tropospheric photolysis rates in clear and cloudy atmospheres. J. Geophys. Res. Atmos. 1999, 104, 23697-23707. [CrossRef]

47. Stamnes, K.; Tsay, S.C.; Wiscombe, W.; Jayaweera, K. Numerically stable algorithm for discrete-ordinate-method radiative transfer in multiple scattering and emitting layered media. Appl. Opt. 1988, 27, 2502-2509. [CrossRef] 
48. Berhanu, T.A.; Savarino, J.; Bhattacharya, S.K.; Vicars, W.C. $17 \mathrm{O}$ excess transfer during the $\mathrm{NO}_{2}+\mathrm{O}_{3}->\mathrm{NO}_{3}+\mathrm{O}_{2}$ reaction. J. Chem. Phys. 2012, 136, 044311. [CrossRef]

49. Liu, S.C.; Kley, D.; Mcfarland, M.; Mahlman, J.D.; Levy, H. On the Origin of Tropospheric Ozone. J. Geophys. Res. Ocean. 1980, 85, 7546-7552. [CrossRef]

50. Liu, S.C.; Trainer, M.; Fehsenfeld, F.C.; Parrish, D.D.; Williams, E.J.; Fahey, D.W.; Hubler, G.; Murphy, P.C. Ozone Production in the Rural Troposphere and the Implications for Regional and Global Ozone Distributions. J. Geophys. Res. Atmos. 1987, 92, 4191-4207. [CrossRef]

51. Bao, H.; Lyons, J.R.; Zhou, C. Triple oxygen isotope evidence for elevated $\mathrm{CO}_{2}$ levels after a Neoproterozoic glaciation. Nature 2008, 453, 504-506. [CrossRef] 